\title{
Bivalve Characterization Using Synchrotron Micro X-Ray Fluorescence
}

\author{
K.W. Jones ${ }^{a}$, S. Bronson ${ }^{a}$, P. Brink ${ }^{b}$, C. Gordon ${ }^{b}$, K. Mosher-Smith ${ }^{c}$, M. Brown ${ }^{d}$,

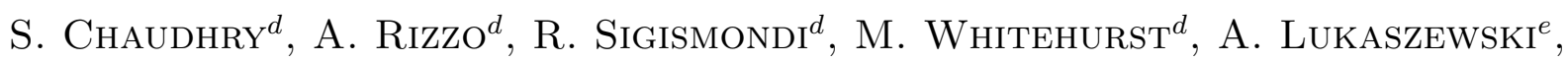 \\ D. Kranz ${ }^{e}$, K. Bland ${ }^{e}$, D. Gordan ${ }^{e}$, J. Lobel $^{e}$, J. Sullivan $^{e}$, M. Metzger $^{f}$, \\ C. O'Shea ${ }^{f}$, C. Harris ${ }^{g}$, R. Arezzo ${ }^{h}$ And M.S. Kambhampati ${ }^{i}$ \\ ${ }^{a}$ Brookhaven National Laboratory, Upton, NY 11973-5000, USA \\ ${ }^{b}$ Stony Brook University, Stony Brook, NY 11794-8661, USA \\ ${ }^{c}$ Gowanus Dredgers' Community Oyster Garden, Brooklyn NY, 11215, USA \\ ${ }^{d}$ Sayville High School, West Sayville, NY 11796, USA \\ ${ }^{e}$ Syosset High School, Syosset, NY 11791-3200, USA \\ ${ }^{f}$ Southampton High School, Southampton, NY 11968, USA \\ ${ }^{g}$ Washington Mathematics Science And Technology Public Charter High School \\ Washington, DC 20003, USA \\ ${ }^{h}$ NY Harbor School, Brooklyn, NY 11237, USA \\ ${ }^{i}$ Southern University at New Orleans, New Orleans, Louisiana 70126, USA
}

\begin{abstract}
Bivalves, oysters, mussels, and clams are important constituents of riverine and estuarine ecosystems. Their shells and soft tissues provide information on the environments in which they live. Since they are filter feeders, they also are factors in improving water quality through removal of particulate matter from the water column. Finally, they are a valuable food source that has substantial economic value. Hence, characterization of shells and soft tissues is useful for improved understanding of these factors. Here, we used X-ray microprobes and computed microtomography facilities at the Brookhaven National Synchrotron Light Source to investigate elemental distributions in bivalves taken from locations around New York, Washington, DC, and New Orleans, LA. The results form the initial basis for compilation of a database of relevant parameters that can serve for tracking environmental changes and for assessing toxicity of particular metals. The work was enabled by active collaboration with students from the several regions, community groups, and research scientists. The collaboration was facilitated through use of web conferencing between Brookhaven National Laboratory and the varied locations.
\end{abstract}

PACS numbers: 01.40.-d, 07.85.Qe, 82.80.Ej, 87.59.--e

\section{Introduction}

Bivalves, including oysters, clams, and mussels are important constituents of estuarine and riverine environments. They are filter feeders and are important factors in improving water quality. The beds of shells that they create are important for support of fish populations [1]. They are also an important food source for natural predators in the water to human predators on land. However, at this time, their abundance has been sharply reduced by adverse changes in their habitat caused by human activities and by too vigorous harvesting for human consumption. Hence, many efforts are now going on aimed at restoring shellfish populations. A summary report on the status of the eastern oyster has been prepared by the National Marine Fisheries Service [2] and for the mussel [3]. Active restoration work is now in progress on the
Hudson-Raritan and Great South Bay estuaries $[4,5]$. Teams drawn from government agencies and from concerned environmental groups worked as partners to establish and monitor progress. The importance of the volunteer contribution is underscored in a publication of the Nature Conservancy that gives guidelines for restoration efforts [6].

There is also interest in biomineralization in bivalves at the molecular scale. Experiments investigating the mechanisms involved in growth have been investigated at the National Synchrotron Light Source (NSLS) using small angle X-ray scattering and other techniques $[7,8]$. Two groups applied synchrotron micro X-ray fluorescence (XRF) techniques to make measurements of metals in whole shells thus bridging the gap between the molecular and field scales $[9,10]$. In another type of experiment, Reinfelder et al. [11] performed laboratory measurements 
on assimilation and removal of trace elements from different bivalves. The results help in understanding how they can be employed in monitoring environmental conditions.

We report here on work that contains elements of all of these topics. Our interests are to characterize bivalves from different locations to ascertain effects caused by the environments in which they live. The results can be helpful in planning and executing projects for restoring shellfish populations. In addition, we hope to relate the results to the biomineralization process and to determining targets for accumulation of toxic elements and compounds. The work is enhanced through interactions with the many stakeholders interested in bivalves. In particular, we have stressed collaboration with high school students and teachers as an essential part of our research. We use web-based conferencing as a mechanism for working with schools that are widely dispersed geographically [12]. This gives students access to experiments in progress while analyzing samples that they have collected combined with the ability to carry on simultaneous discussions with teachers and scientists. The education and scientific activities are integrated through collaboration of Brookhaven National Laboratory (BNL) staff in scientific departments and the Office of Educational Programs.

We chose to make analytical measurements using the synchrotron XRF method for several reasons. First, the $\mathrm{X}$-ray beams from the synchrotron source can be focused to a size around $10 \mu \mathrm{m}$ enabling high-resolution spatial measurements. Second, the X-ray flux is high, enabling measurements of trace elements with detection levels in the parts-per-million range. Third, the XRF technique gives simultaneous multi-element detection. Fourth, the beam energy can be varied to optimize detection for specific elements. Fifth, the technique is nondestructive compared to methods such as scanning electron microscopy. Sixth, sample preparation and handling is simplified since the work is done at atmospheric pressure. The results from the XRF work can be used to guide further experiments using other techniques such as electron probe or transmission electron microscopy to obtain better spatial resolution and by use of cytochemical methods to establish metal-protein correlations.

\section{Materials and methods}

Our group obtained a varied collection of bivalve specimens of oysters (Crassostrea virginica), mussels (Geukensia demissa), and Quahog clams (Mercenaria mercenaria) from a number of locations in the eastern and southern United States. Our high school groups were responsible for most of the work and subsequent preparation for analysis as part of their school's environmental education programs. A summary of the geographical locations is given in the Table. We also exposed a small section of $8 \mu \mathrm{m}$ polyimide film to the water column of the Gowanus Canal in Brooklyn, NY for a month by placing it in a holder in the wire basket used for growing oysters. A substantial film of fine sediment and, presumably, biomaterials accumulated over that time. Measurements with the X-ray beams of the NSLS gave a picture of the metals that constituted part of the diet of the local oysters and mussels.

TABLE

Summary of collection locations and sample type.

\begin{tabular}{|c|c|c|c|}
\hline Location & $\begin{array}{r}\text { North } \\
\text { latitude }\end{array}$ & $\begin{array}{c}\text { West } \\
\text { longitude }\end{array}$ & $\begin{array}{c}\text { Sample } \\
\text { type }\end{array}$ \\
\hline $\begin{array}{l}\text { Shinnecock Inlet, } \\
\text { Long Island, NY }\end{array}$ & $40^{\circ} 50.47^{\prime}$ & $72^{\circ} 2.67^{\prime}$ & $\begin{array}{l}\text { mussel, } \\
\text { oyster }\end{array}$ \\
\hline $\begin{array}{l}\text { Towd Point, Long } \\
\text { Island, NY }\end{array}$ & $40^{\circ} 56.62^{\prime}$ & $72^{\circ} 24.08^{\prime}$ & $\begin{array}{l}\text { mussel, } \\
\text { oyster }\end{array}$ \\
\hline $\begin{array}{l}\text { Scallop Pond, Long } \\
\text { Island, NY }\end{array}$ & $40^{\circ} 56.28^{\prime}$ & $72^{\circ} 25.97^{\prime}$ & mussel \\
\hline $\begin{array}{l}\text { Gowanus Canal, } \\
\text { Brooklyn, NY }\end{array}$ & $40^{\circ} 40.62^{\prime}$ & $73^{\circ} 5.40^{\prime}$ & $\begin{array}{l}\text { oyster, } \\
\text { mussel }\end{array}$ \\
\hline $\begin{array}{l}\text { Hudson River, Pier } \\
\text { 42. NY, NY }\end{array}$ & $40^{\circ} 43.70^{\prime}$ & $74^{\circ} 0.18^{\prime}$ & oyster \\
\hline $\begin{array}{l}\text { Captree Island, Great } \\
\text { South Bay, Long } \\
\text { Island, NY }\end{array}$ & $40^{\circ} 38.21^{\prime}$ & $73^{\circ} 15.09^{\prime}$ & oyster \\
\hline $\begin{array}{l}\text { Cold Spring Harbor, } \\
\text { Long Island, NY }\end{array}$ & $40^{\circ} 52.12^{\prime}$ & $73^{\circ} 38.08^{\prime}$ & mussel \\
\hline $\begin{array}{l}\text { Potomac River, } \\
\text { Washington, DC }\end{array}$ & $52^{\circ} 16.83^{\prime}$ & $76^{\circ} 75.05^{\prime}$ & clam \\
\hline $\begin{array}{l}\text { Louisiana } \\
\text { Universities Marine } \\
\text { Consortium } \\
\text { (LUMCON) } \\
\text { Wetlands, Cocodrie, } \\
\text { Louisiana }\end{array}$ & $29^{\circ} 15^{\prime}$ & $90^{\circ} 40^{\prime}$ & $\begin{array}{l}\text { oyster, } \\
\text { mussel }\end{array}$ \\
\hline
\end{tabular}

The specimens were prepared for analysis at the NSLS by washing the shells and brushing off external sediments. The soft tissues were oven dried, ground to a powder in a mortar and pestle, and pressed into small pellets. A $65 \mu \mathrm{m}$ section of a Gowanus oyster was made using a cryomicrotome. This specimen was used to demonstrate feasibility of mapping metals to specific tissue locations. These were then mounted for analysis at NSLS beam lines X26A, X27A, and X2b. Shells were also sectioned so that measurements could be made across the shell from its exterior surface to its interior surface.

$\mathrm{X}$-ray fluorescence measurements were made at the $\mathrm{X} 27 \mathrm{a}$ and X27A microprobe beam lines. They both are configured with an adjustable collimator, silicon monochromator, and Kirkpatrick-Baez type focusing mirrors. The X-ray beam size is approximately $6 \mu \mathrm{m} \times 10 \mu \mathrm{m}$ for X26a and $10 \mu \mathrm{m} \times 15 \mu \mathrm{m}$ for X27A. There is a choice of detectors at X26A, either a Si-drift detector or 9-element $\mathrm{Ge}(\mathrm{I})$ detector can be used. X27A uses a 13-element $\mathrm{Ge}(\mathrm{I})$ detector. Detection limits for 
transition elements are about $1 \mathrm{fg}$ for both beam lines. Both can be used for making single-point analyses or for making maps. A computed microtomography measurement was made at beam line X2B. The tomographic data are obtained using a CsI $(\mathrm{Tl})$ scintillator viewed by a CCD camera. The voxel size that was used was $4 \mu \mathrm{m}$.

Complementary electrophoresis gel measurements were made on the soft tissue of the oysters to obtain information on the distribution of proteins in the tissue and possible determination of metal binding proteins. Cell protein lysates were extracted by treatment of the tissues on ice with RIPA buffer containing PMSF, protease inhibitors and sodium orthovanadate. The lysed tissues were centrifuged at $14,000 \mathrm{rpm}$ for $10 \mathrm{~min}$ at $4^{\circ} \mathrm{C}$. The supernatant was collected from each and a Bradford assay was done to determine protein contents. Samples were mixed with SDS sample buffer, boiled for $5 \mathrm{~min}$ and proteins were separated by electrophoresis on a $10 \%$ SDS-PAGE. (At this point two different procedures were used.) Procedure 1 - after the proteins were separated on a $10 \%$ SDS-PAGE the proteins were made visible by placing the polyacrylamide gel in Coomassie Blue R-250 stain then destaining. The gel was dried between 2 sheets of cellophane then analyzed at the NSLS. Procedure 2 after the proteins were separated on a 10\% SDS-PAGE the proteins were transferred to Immobilon-P membrane (Millipore) then analyzed at the NSLS. Relative protein concentrations were found by making an optical scan of the stained gel.

\section{Discussion and conclusions}

We illustrate the types of data that we obtained using selected samples from some of the sites listed in Table. Examples of the X-ray spectra for the shells and soft tissues, maps of metal concentrations in the shells and soft tissue, results for eletrophoresis scans, and a tomographic section are shown in the figures.

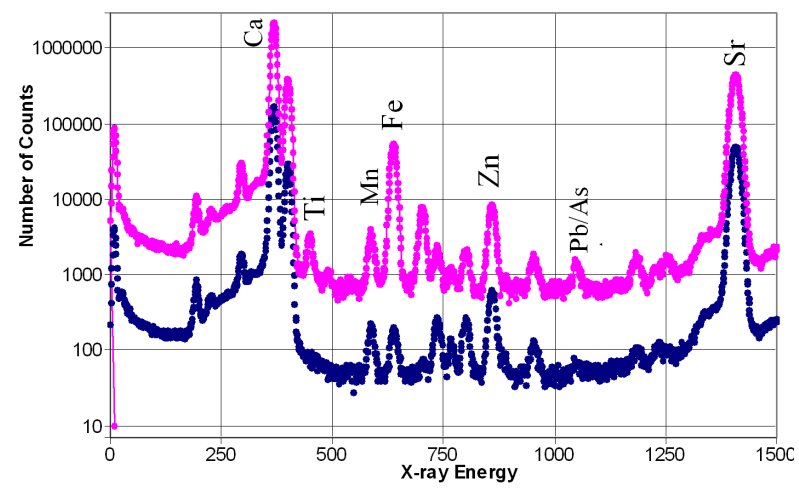

Fig. 1. X-ray spectra for oysters taken from Shinnecock Inlet (bottom data) at an energy of $17.5 \mathrm{keV}$ and from the Gowanus Canal (top data) at an energy of $16.5 \mathrm{keV}$ are shown. The Gowanus data was multiplied by 10 to facilitate comparisons.

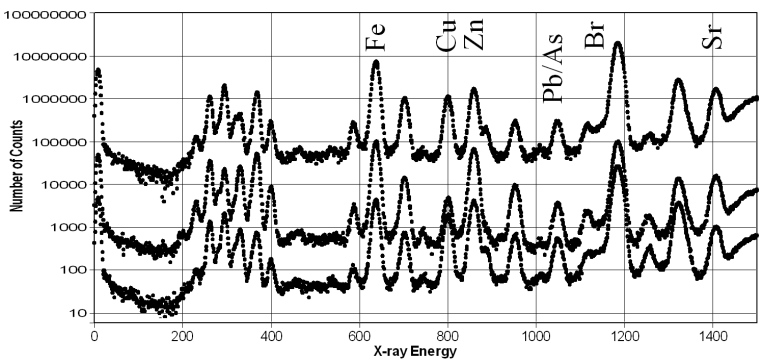

Fig. 2. X-ray spectra for gills (bottom), feet (middle), and adductor muscle (top) from a Gowanus Canal mussel are shown.

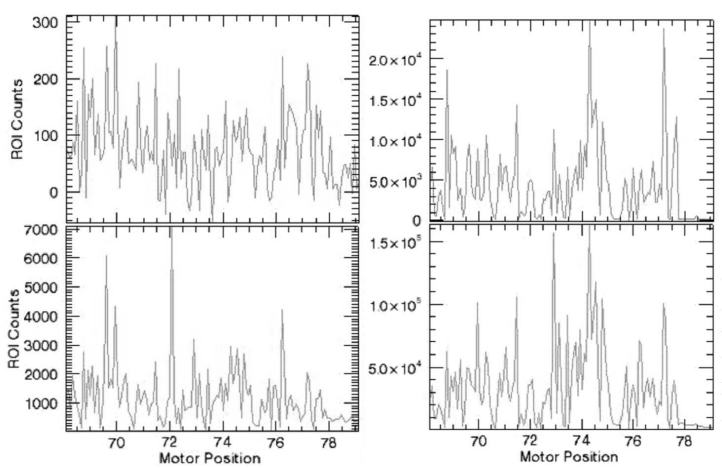

Fig. 3. XRF line scan along the left valve of a 1-year old Gowanus Canal Oyster shell. The scan extends from the oldest portion of the shell to the newest. The abscissa gives the sample position in $\mathrm{mm}$. The step size was $25 \mu \mathrm{m}$. Starting with the top left plot and going clockwise, data for $\mathrm{Pb}, \mathrm{Cu}, \mathrm{Zn}$, and $\mathrm{Ca}$ are given.

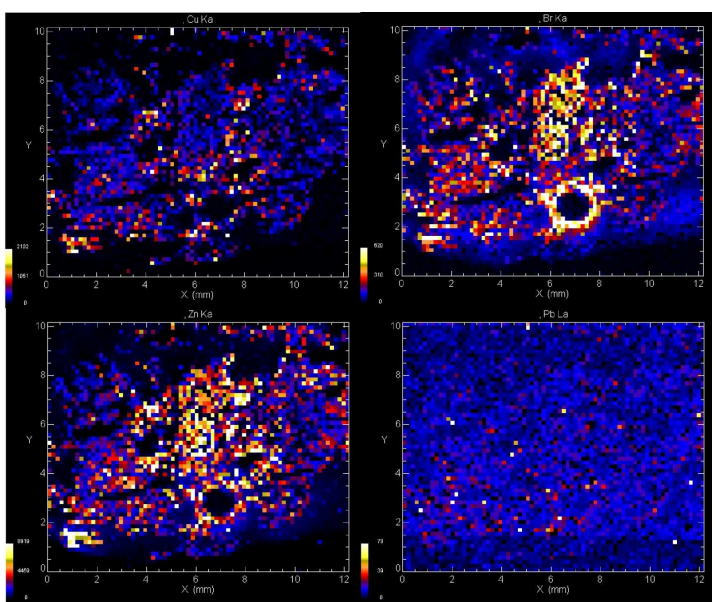

Fig. 4. Elemental XRF scans on a $65 \mu \mathrm{m}$ section from a complete 1-year old Gowanus Canal oyster. The dwell time was $9 \mathrm{~s}$ and the $x, y$ step size was $160 \mu \mathrm{m}$. The relative concentrations of each element are shown by variations in color ranging from low concentrations (dark) to high concentrations (white). 


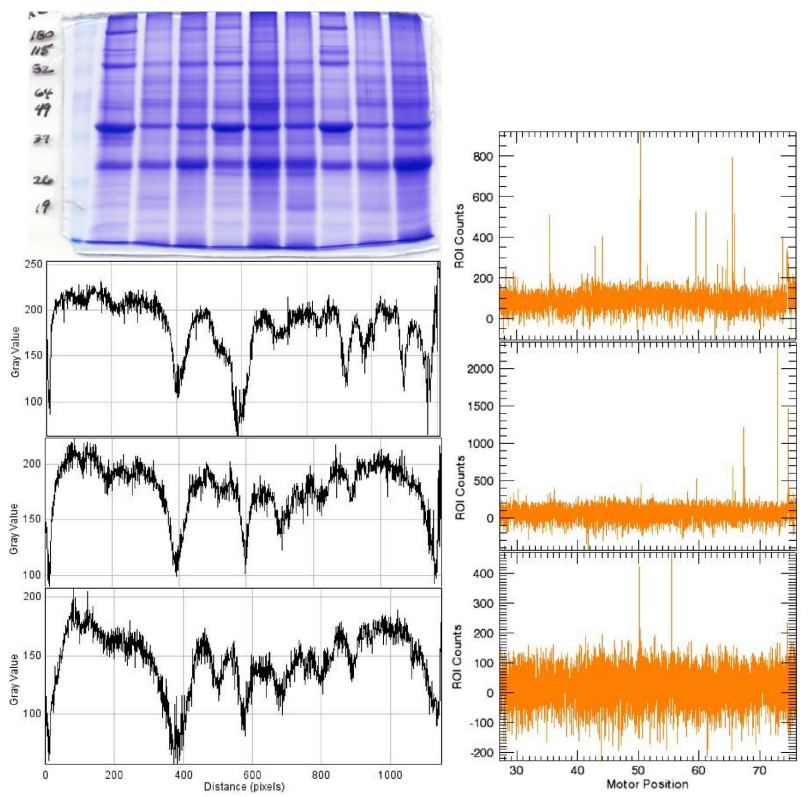

Fig. 5. Results of optical scanning of electrophoresis gels of tissues obtained from a one-year old oyster from the Gowanus Canal. The left column of the figure shows, from top to bottom: the protein bands in the gel, followed by optical scans showing relative concentrations in the protein bands for muscle, gills, and organs as a function of the molecular weights. The weights increase with increasing distance (abscissa) along the band. The three plots on the right show, from top to bottom, XRF scans of $\mathrm{Cu}, \mathrm{Zn}$, and $\mathrm{Pb} / \mathrm{As}$.

Typical X-ray spectra obtained for oyster shells from the Shinnecock Inlet, Great South Bay and the Gowanus Canal are given in Fig. 1. The elements corresponding to particular peaks are shown in the figure. The Shinnecock shell was taken as representative of a relatively uncontaminated region. Specific instances of anthropogenic contaminants include $\mathrm{Ti}, \mathrm{As}$, and $\mathrm{Pb} . \mathrm{Cu}$ and $\mathrm{Zn}$ are potentially toxic elements if found in sufficient concentrations, but they can also be naturally occurring in components of the bivalve diets. Spectra obtained for soft tissue taken from a Gowanus Canal mussel are given in Fig. 2. Potentially toxic metals are found in all three types of material. The concentrations of metals were measured as a function of distance along the shell of several specimens. Results of a scan obtained from examination of a small oyster shell from the Gowanus Canal are shown in Fig. 3. Concentrations are highly variable showing differences at different times in the oyster's growth.

Maps of the $\mathrm{Cu}, \mathrm{Zn}, \mathrm{Pb} / \mathrm{As}$ and $\mathrm{Br}$ concentrations found in the thin section of tissue from a Gowanus Canal oyster are given in Fig. 4. Preferential uptake at specific locations is indicated by the lighter-colored pixels (higher relative concentrations) clustered in different regions of the plots. We have not correlated the Zn map with specific organs at this time. This map clearly shows that the synchrotron XRF technique has sufficient sensitivity to be used as a tool for looking at the pathways for accumulation in specific tissue types. We used electrophoresis gel measurements to show variations in protein composition. The results of an optical scan of a stained gel and an Xray scan for Zn are shown in Fig. 5. The X-ray data does show a few points with measurable Zn. Further work is needed to improve the signal-to-noise ratio and to show that this is truly related to a protein.

Our computed microtomography measurement was made to ascertain the variability in X-ray absorption in a small cross-section through the shell. Results for a single section are shown in Fig. 6. The composition is quite uniform, but variability is observed. Additional work is needed to correlate the data obtained through scans along the surface of the shell with measurements made on a cross-section of the shell.

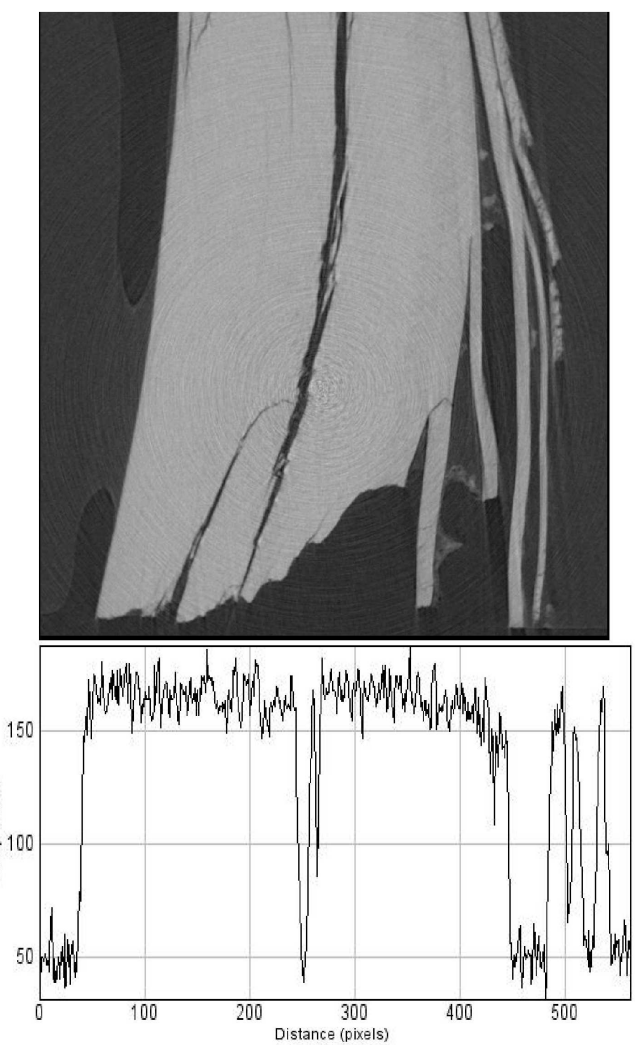

Fig. 6. Microtomogram showing a transverse section through a small portion of an oyster shell from the inside on the left to the outside on the right is presented at the top of the figure. The shell thickness is about $4 \mathrm{~mm}$. The pixel size is $4 \mu \mathrm{m}$. Variability in the attenuation coefficient is observed as shown in the plot of the values found in a transect across the sample. Fragmentation observed results from the sample preparation.

We believe that the data reported here demonstrate the usefulness of bivalves as an environmental indicator, show ways in which the synchrotron technique can be used in conjunction with biological techniques to evaluate pathways for metal accumulation. Expansion of the program scope will be valuable from the standpoint of 
basic and applied environmental science as well as for its role in scientific education.

\section{Acknowledgments}

Work supported by the U.S. Department of Energy under contract No. DE-AC02-98CH19886. The NSLS is supported through the U.S. Department of Energy Office of Basic Energy Sciences. We thank the Louisiana Fisheries and Wildlife, Louisiana Universities Marine Consortium (LUMCON), and Coastal Restoration and Enhancement through Science and Technology (CREST) Program for enabling collection of specimens in Louisiana.

\section{References}

[1] L.D. Coen, R.E. Grizzle, Habitat Management Series 8, ii-108 (2007).

[2] Eastern Oyster Biological Review Team, 2007, Status review of the eastern oyster (Crassostrea virginica). Report to the National Marine Fisheries Service, Northeast Regional Office, February 16, 2007.

[3] National Status and Trends Program: Mussel Watch Project, http://www.hsrl.rutgers.edu/NST.html.
[4] Hudson-Raritan Estuary Restoration efforts are summarized at the NY/NJ Baykeeper web site: http://www.nynjbaykeeper.org/programs/42.

[5] K.R. Hinga, Technical Report NPS/NER/NRTR, 019 (2005).

[6] R.D. Brumbaugh, M.W. Beck, L.D. Coen, L. Craig, P. Hicks, A Practioners Guide to the Design 86 Monitoring of Shellfish Restoration Projects, The Nature Conservancy, Arlington (VA) 2006.

[7] I.W. Kim, E. DiMasi, J.S. Evans, Cryst. Growth $\&$ Design 4, 1113 (2004).

[8] K. Subburaman, N. Pernodet, S.Y. Kwak, E. DiMasi, S. Ge, V. Zaitsev, X. Ba, N.L. Yang, M. Rafailovich, Proc. Natl. Acad. Sci. 103, 14672 (2006).

[9] K. Thorn, R.M. Cerrato, M.L. Rivers, Biol. Bull. 188, 57 (1995).

[10] S. Kurunczi, S. Török, P. Chevallier, Mikrochim. Acta 137, 41 (2001).

[11] J.R. Reinfelder, W.-X. Wang, S.N. Luoma, N.S. Fisher, Mar. Biol. 129, 443 (1997).

[12] K. Snyder, Synchrotron Radiat. News 21, 40 (2008). 